\title{
O PATERNALISMO JURÍDICO-PENAL E A JURISPRUDÊNCIA DO SUPREMO TRIBUNAL FEDERAL
}

\author{
THE LEGAL PATERNALISM AND THE JURISPRUDENCE OF \\ BRAZILIAN SUPREME COURT
}

\author{
João Paulo Orsini Martinelli ${ }^{1}$ \\ Universidade Federal Fluminense \\ Humberto Soura Santos ${ }^{2}$
}

Universidade do Estado do Rio de Janeiro

\begin{abstract}
Resumo
O presente artigo expõe o princípio da autonomia como um dos fundamentos da proteção dos bens jurídicos mais importantes pelo direito penal. O princípio da autonomia delimita o poder punitivo do Estado para impedir a punição de fatos pouco lesivos ou apenas imorais. A jurisprudência do Supremo Tribunal Federal, como demonstraremos, não está adequada aos limites do princípio da ofensividade e, muitas vezes, é influenciada pelo mero moralismo legal.
\end{abstract}

Palavras-chave

Autonomia. Liberdade. Pena. Vulnerabilidade. Proteção.

\section{Abstract}

This article exposes the principle of autonomy as one of the bases of protection of the most important legal interests by Criminal Law. The principle of autonomy delimits the punitive power of the State to prevent the punishment of facts that are not harmful or are just immoral. The jurisprudence of the brazilian Supreme Court, as we shall demonstrate, is not adequate to the limits of harm principle and is often influenced by mere legal moralism.

Keywords

Autonomy. Liberty. Punishment. Vulnerability. Protection.

${ }^{1}$ Professor de Direito Penal da Universidade Federal Fluminense - UFF. Pós-Doutor em Direito pela Universidade de Coimbra. Doutor e Mestre em Direito Penal pela Universidade de São Paulo - USP. Graduado em Direito pela Universidade de São Paulo USP. Advogado.

${ }^{2}$ Doutorando em Direito Penal pela Universidade do Estado do Rio de Janeiro - UERJ. Mestre em Ciências Penais pela Universidade Cândido Mendes - UCAM. Graduado em Direito pela Faculdade Nacional de Direito da Universidade Federal do Rio de Janeiro UFRJ. Advogado. 


\section{INTRODUÇÃO}

O direito penal de um Estado liberal e democrático de direito devese pautar pelos princípios tradicionais, entre eles o da legalidade, da subsidiariedade, da lesividade, da fragmentariedade e da proporcionalidade. No entanto, a tais princípios é preciso adicionar o princípio da autonomia individual, segundo o qual as proibições penais devem respeitar ao máximo a liberdade do sujeito, pois é de se presumir que cada um sabe o que é melhor para si próprio. E tal se afirma isso com plena consideração ao fato de que a tradição jurídico-penal romano-germânica, predominante na Europa continental e na América Latina, tem como núcleo a teoria do bem jurídico, que parte do objeto de proteção para a elaboração da norma, enquanto, por outro lado, a tradição anglo-saxã, da common law, parte dos princípios da lesão (harm principle) e da ofensa (offense principle), rejeitando a criminalização de condutas com fundamento unicamente na imoralidade que podem representar ao meio social (moral principle). Isso porque aqui se acredita que ambas as concepções não são excludentes, mas podem ser complementares, já que, nos dois sistemas jurídicos há um ponto em comum: a ideia de que o direito penal deve ser a ultima ratio do controle social formal.

O presente trabalho tem como objetivo apresentar as estruturas da argumentação, de matriz anglo-saxã, que reconhece a presença de espécies de paternalismo estatal em normas jurídico-penais diante de uma análise da jurisprudência do Supremo Tribunal Federal aplicada em casos concretos e no controle de constitucionalidade de leis em abstrato em que tal paternalismo jurídico-penal era evidente. Isso com o fim de demonstrar que tais argumentos podem servir para, no âmbito de nossa Corte Suprema, esclarecer os limites da intervenção estatal na liberdade do indivíduo, de acordo com uma aplicação liberal das normas penais.

\section{LIBERDADE E AUTONOMIA}

Em primeiro lugar, é preciso partir da seguinte premissa: o direito penal deve respeitar a autonomia individual. Isso significa que, para além da 
análise do bem jurídico tutelado, o núcleo da criação e da interpretação dos tipos penais é a liberdade individual. Além do interesse humano que se pretende tutelar - e os comportamentos perigosos ou lesivos que se quer evitar - é fundamental considerar o titular do bem jurídico e sua autonomia para dispor da proteção do Estado se assim o desejar. A pessoa autônoma tem o direito de exercer sua liberdade conforme sua dignidade e o Estado deve respeitar sua vontade, sob pena de configurar arbitrariedade e contrariedade ao Estado democrático de Direito. A ordem democrática impede a interferência abusiva na liberdade individual em nome de uma suposta proteção imposta indiscriminadamente.

Uma concepção de Estado democrático de Direito deve pautar-se na valorização da autonomia individual pela qual a pessoa possa decidir e agir conforme sua consciência, desde que não atinja diretamente interesses de terceiros. Portanto, o fundamento moral da criminalização deve ser compreendido como meio de assegurar a identidade da humanidade (generalidade das pessoas), e o Estado deve assumir papel imparcial na imposição de comportamentos e respeitar as particularidades de cada um. Esse ponto de vista moral permite a concepção de uma justiça universal orientada à auto-realização pessoal fundada na coerência e maturidade da pessoa. ${ }^{3}$ Autonomia é palavra que tem origem nos termos auto (próprio) e nomos (norma ou regra). Ser autônomo é "possuir ou construir suas próprias leis". ${ }^{4}$ No plano jurídico, o conteúdo político de autonomia aplica-se ao conceito de sujeito individual: a pessoa autônoma é aquela que pode conduzir sua vida conforme seus preceitos, sua consciência e sua vontade ${ }^{5}$.

A autonomia individual é um conceito geralmente compreendido em referência à capacidade de ser si próprio, de viver a própria vida de acordo com as razões e motivos considerados próprios e não produtos de forças externas manipuladoras ou distorcidas. É o valor central na filosofia moral de tradição kantiana além de ser fundamental na versão do liberalismo

3 FERRARA, Alessandro. Two Notions of Humanity and the Judgment Argument for

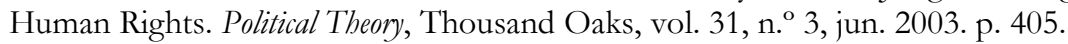

${ }^{4}$ FEINBERG, Joel. Harm to self. Nova Iorque: Oxford. 1986. p. 27.

5 SEGRE, Marco, LEOPOLDO E SILVA, Franklin, SCHRAMM, Fermin R. O contexto histórico, semântico e filosófico do princípio de autonomia. Bioética, Brasília, DF, vol. 06, 1998. p. 15. 
utilitário de STUART MILL' ${ }^{6}$ Ser autônomo é ser dirigido por considerações, desejos, condições e características próprios, e não simplesmente impostos externamente. Autonomia, assim, é um valor irrefutável, especialmente porque o seu oposto - ser guiado por forças externas que não podem ser consideradas autênticas - aproxima-se do conceito de repressão ${ }^{7}$.

Todavia, é preciso se atentar às diferenças entre autonomia e liberdade, uma vez que não se confundem enquanto conceitos. Tal distinção é fundamental para compreender as teses legitimadoras da intervenção penal na liberdade individual em determinadas situações. Enquanto a liberdade é um conceito que se refere a um ato particular, autonomia diz respeito ao estado da pessoa ${ }^{8}$. A autonomia é um conceito mais global, é uma característica que avalia todo um modo de vida e não apenas um curto período de tempo. Liberdade é um conceito mais restrito, relacionado a um ato isolado, que nem sempre implica autonomia. Entretanto, tais conceitos estão estritamente relacionados, pois a liberdade é condição necessária para o indivíduo desenvolver seus próprios objetivos e interesses e tornar seus valores pessoais efetivos em sua vida?

O valor da autonomia pode ser verificado por dois pontos de vista diferentes. O primeiro considera a autonomia conforme o valor do objeto da escolha, ou seja, a autonomia é valorada de acordo com a escolha que se pretende fazer; outro ponto de vista considera o valor da autonomia por si só, quer dizer, independentemente daquilo para o quê se quer usar a liberdade $^{10}$. Em outras palavras, e inserindo tal distinção no direito penal, a autonomia pode ter seu valor atrelado ao bem jurídico tutelado pela norma penal - e daí a possibilidade de se classificar determinados bens como

${ }^{6}$ CHRISTMAN, John. Autonomy in Moral and Political Philosophy. Stanford Encyclopedia of Philosophy. Disponível em: <http://plato.stanford.edu/entries/autonomy-moral/>. Acesso em: 10/06/2014.

7 Idem, ibidem.

${ }^{8}$ DWORKIN, Gerald. The Theory and Practice of Autonomy. Nova Iorque: Cambridge University Press. 1988. p. 14.

${ }^{9}$ Idem, ibidem. p. 18.

${ }^{10}$ YOUNG, Robert. The Value of Autonomy. The Philosophical Quarterly, vol. 32, n.o 126, jan. 1982. p. 35. 
indisponíveis - ou, ainda, pode-se desconsiderar o bem e considerar a autonomia por si só - o que permite confirmar a inexistência de bens indisponíveis.

Em relação à liberdade, a filosofia moral costuma fazer a distinção em suas dimensões positiva e negativa. Por liberdade negativa compreendese a falta de obstáculos, barreiras ou restrições, enquanto a liberdade positiva é a possibilidade de alguém agir ou atuar de tal forma a assumir o controle de sua vida e atingir seus propósitos ${ }^{11}$. Essa distinção é importante para a concepção liberal do Direito Penal, pois refere-se aos limites de intervenção da atividade do Estado. Desse modo, a liberdade individual, em seu sentido negativo, é inversamente proporcional à intensidade da criminalização de comportamentos. Pode-se concluir, assim, que o direito penal é instrumento de controle social formal que impõe um padrão mínimo de comportamento em sociedade para uma vida social harmônica e, portanto, é necessário atender a diversos e rigorosos requisitos para criminalizar condutas ${ }^{12}$.

A distinção entre autonomia e liberdade, assim, conduz à seguinte indagação: o direito penal tutela a liberdade ou a autonomia? Dos conceitos apresentados, extrai-se que as normas penais, apesar de genéricas e abstratas, atuam em casos concretos e, portanto, restringem a liberdade individual para evitar resultados lesivos. A norma penal deve preservar a autonomia e, para isso, em algumas situações deve respeitar a liberdade, mesmo que o bem jurídico tutelado sofra algum tipo de lesão. Da mesma maneira que fez GERALD DWORKIN em seu clássico artigo Paternalism ${ }^{13}$, recorre-se a STUART MILL para fundamentar a proteção à autonomia: "nenhuma pessoa, ou grupo de pessoas, está autorizada a dizer a outra criatura humana, em idade madura, que esta não deve fazer aquilo que escolbeu para sua vida porque não

11 CARTER, Ian. Positive and Negative Liberty. Stanford Encyclopedia of Philosophy. Disponível em <http://plato.stanford.edu/entries/liberty-positive-negative/>. Acesso em: $11 / 06 / 2014$.

12 JAREBORG, Nils. Criminalization as Last Resort (Ultima Ratio). Obio State Journal Of Criminal Law, Columbus, vol. 02, 2004. p. 527

${ }^{13}$ DWORKIN, Gerald. Paternalism. In: FEINBERG, J.; GROSS, H. (orgs.). Philosophy of Law. Encino (EUA): Dickenson Publisling. 1975. pp. 230-239. Também há versão do artigo traduzida para o português: DWORKIN, Gerald. Paternalismo. Trad. João Paulo Orsini Martinelli. Revista Justiça e Sistema Criminal, vol. 4, n. 6, jan./jun. 2012, pp. 07-26. 
baverá nenbum benefício". No que se refere ao Direito Penal, a assertiva vale para o Estado na figura de seus agentes públicos, dentre os quais os legisladores e os aplicadores da lei.

\section{CONCEITO DE PATERNALISMO}

No conceito declaradamente superficial de DWORKIN, "paternalismo é a interferência sobre a liberdade de ação de alguém justificada por razões referentes exclusivamente ao bem-estar, ao benefício, à felicidade, às necessidades, aos interesses ou aos valores da pessoa coagida" ${ }^{14}$. Assim, é possível conceituar paternalismo como a interferência na liberdade individual, contra a vontade de alguém, com a finalidade de promover-lhe um bem ou evitar-lhe um mal. No caso do direito penal, a norma paternalista é aquela que pune determinado comportamento por entender que este é prejudicial a alguém, mesmo quando praticado com o consentimento do titular do bem jurídico. O caráter paternalista de uma norma penal pressupõe o exercício de poder ${ }^{15}$ e faz parte de seu papel no controle social formal, uma vez que há a imposição de determinadas abstenções, cuja finalidade é a proteção de bens jurídicos em situações em que seu titular consente na criação de um risco à sua integridade. Os requisitos de uma norma paternalista estão estruturados em seu fundamento, seu objeto e sua finalidade.

\subsection{Fundamento da norma paternalista}

No Estado Democrático de Direito, o fundamento da norma paternalista é a liberdade individual de viver a própria vida, conforme a autonomia. $\mathrm{O}$ direito penal deve se preocupar com a tutela de bens jurídicos e a liberdade de seu titular. Quer dizer, a liberdade individual é condição necessária para a intervenção penal na proteção de bens jurídicos individuais. Desta afirmação pode-se extrair que não há um padrão único de comportamentos

${ }^{14}$ Dworkin, Gerald. Paternalismo. p. 09.

${ }^{15}$ ALEMANY, Macario. El paternalismo jurídico. Madri: Iustel. 2006. p. 343. 
que deve ser imposto pelas normas, pois a cada um cabe decidir o que fazer da própria vida. O direito penal, assim, deve preservar um padrão axiológico mínimo no qual todos estariam inseridos e de onde emergiriam os discursos e as instituições, inclusive as normas de direito. Há que se manter um padrão mínimo de valores e bens que o sujeito autônomo não dispensaria para proteger seus interesses ${ }^{16}$. A base de um direito penal democrático, portanto, é restringir a liberdade individual para impedir comportamentos lesivos contra o consentimento do titular do bem jurídico.

O processo de criminalização, pelo qual o legislador reconhece a necessidade de criar ou modificar tipos penais, primeiramente deve delimitar o interesse a ser protegido e o comportamento a ser punido. Nesse contexto, não é permitido ao legislador criminalizar autolesões ou comportamentos meramente imorais ${ }^{17}$. Um dos critérios para estabelecer a legitimidade da criminalização de comportamentos encontra-se na versão negativa do moralismo legal, para a qual a (wrongfulness) de uma conduta é condição necessária de criminalização, mas não uma razão positiva. Isto é, não se pode criminalizar um comportamento a não ser que este seja (wrongful), porém, as razões positivas de criminalização estão na lesão ou no perigo de lesão deste comportamento ${ }^{18}$.

\subsection{Objeto da norma paternalista}

Ao adotar o respeito à liberdade como regra geral, por exclusão o objeto da norma paternalista é aquele que, de alguma maneira, não possui autonomia no momento da sua escolha. O sujeito autônomo, com capacidade de discernimento e competente para fazer suas escolhas, deve ser respeitado em suas decisões, em especial pelo Direito Penal quando decide abrir mão da tutela de um bem jurídico do qual seja titular. Assim, num primeiro momento, afirma-se que pessoas autônomas, em princípio,

16 PERRY, Thomas D. Moral Autonomy and Reasonableness. The Journal of Philosophy, Oxford, vol. 65, jun. 1968. p. 368.

${ }^{17}$ MURPHY, Jeffrie G. Legal Moralism and Liberalism. Arizona Law Review, vol. 37, 1995. p. 79.

${ }^{18}$ DUFF, R. A. Towards a Modest Legal Moralism. Legal Studies Research Paper Series - Research Paper n. 12-28, University of Minnesota Law School. pp. 01-02. 
não podem ser objetos de normas paternalistas; de outro lado, os vulneráveis merecem atenção especial do ordenamento jurídico.

Dois pontos merecem atenção quanto ao objeto do paternalismo: (a) quem são as pessoas vulneráveis e como determinar a vulnerabilidade; e (b) a possibilidade de legitimar uma norma paternalista quando o titular do bem jurídico possuir autonomia. O primeiro ponto requer a busca por critérios objetivos e subjetivos de determinação da vulnerabilidade e o segundo entra na esfera da indisponibilidade de alguns bens jurídicos.

\subsubsection{Vulnerabilidade}

Vulneráveis são indivíduos que por certas condições pessoais sociais, culturais, étnicas, políticas, econômicas, educacionais, de saúde possuem diferenças, estabelecidas entre eles e a sociedade que os envolve, transformadas em desigualdade" 19 . Portanto, a vulnerabilidade é indicador de desequilíbrio nas relações pessoais e, para que o equilíbrio seja estabelecido, são necessárias interferências externas. O vulnerável não possui capacidade de discernimento e é incapaz de cuidar de si mesmo, por isso, requer cautela especial. ${ }^{20}$

O Supremo Tribunal Federal utiliza argumentos nesse sentido para manter a interpretação de presunção absoluta de violência e confirmar a irrelevância do consentimento da vítima menor de catorze anos nos casos de estupro de vulnerável, mesmo após a nova redação dada pela Lei 12.015/2009 ao artigo 217-A do Código Penal. Assim, sua Segunda Turma da Corte Suprema se pronunciou no julgamento do Agravo Regimental no Recurso Extraordinário n. 940701 AgR/SP: “A jurisprudência desta Corte Suprema perfilha entendimento de ser absoluta a presunção de violência nos casos de crime de estupro praticado contra menor de catorze anos (estupro de vulnerável), independentemente da conduta ter sido praticada,

\footnotetext{
${ }^{19}$ GUIMARÃES, Maria Carolina S., NOVAES, Sylvia Caiuby. Vulneráveis. Portal da Bioética da Universidade Federal do Rio Grande do Sul. Disponível em <http://www.ufrgs.br/bioetica/vulnera.htm>. Acesso em: 16 jun. 2014.

${ }^{20}$ READER, Soran. New Directions in Ethics: Naturalisms, Reasons and Virtue. Ethical Theory and Moral Practice, Amsterdan (Holanda), vol. 3, n. ${ }^{\circ}$ 04, dez. 2000. p. 346.
} 
antes ou depois, da vigência da Lei 12.015/2009. Precedentes." ${ }^{21}$ E, de fato, no julgamento do Habeas Corpus 93263 RS, ainda sob a redação antiga do artigo 224, a, do Código Penal, a mesma Primeira Turma já havia se manifestado no sentido de que "é firme a jurisprudência deste Supremo Tribunal no sentido de que o eventual consentimento da ofendida, menor de 14 anos, para a conjunção carnal e mesmo sua experiência anterior não elidem a presunção de violência, para a caracterização do estupro. Precedentes. " 22 E os precedentes que resguardam tal orientação do STF de ignorar o consentimento da vítima menor de catorze anos com o ato sexual realmente são vários e podem ser mencionados o Recurso Ordinário em Habeas Corpus n. 80.613/SP ${ }^{23}$ e o Habeas Corpus n. 81.268. ${ }^{24}$

$\mathrm{O}$ único julgado que parece destoar desse tradicional entendimento é o do Habeas Corpus n. 73.662/MG, também proferido sob a redação antiga, em que a Segunda Turma afirmou que: “O estupro pressupõe o constrangimento de mulher à conjunção carnal, mediante violência ou grave ameaça - artigo 213 do Código Penal. A presunção desta última, por ser a vítima menor de 14 anos, é relativa. Confessada ou demonstrada a aquiescência da mulher e exsurgindo da prova dos autos a aparência, física e mental, de tratar-se de pessoa com idade superior aos 14 anos, impõe-se a conclusão sobre a ausência de configuração do tipo penal. Alcance dos artigos 213 e 224, alínea "a", do Código Penal." 25 No entanto, mesmo embora, nesse caso, tenha sido mencionada uma espécie de presunção relativa, condicionou-se, além da demonstração do consentimento da mulher, de provas nos autos que revelem que sua aparência, física ou mental, fazia pressupor se tratar de pessoa com idade superior aos 14 anos, o que mais se refere à ocorrência de erro de tipo do que, propriamente, ao

${ }^{21}$ STF, ARE 940701 AgR/SP, Segunda Turma, Relator Ministro Gilmar Mendes, julgado em $08 / 03 / 2016$.

22 STF, HC 93263/RS, Primeira Turma, Relatora Ministra Cármen Lúcia, julgado em 19 de fevereiro de 2008.

${ }^{23}$ STF, RHC 80613/SP, Primeira Turma, Relator Ministro Ilmar Galvão, julgado em 06 de março de 2001.

${ }^{24}$ STF, HC 81268/DF, Primeira Turma, Relator Ministro Sepúlveda Pertence, julgado em 16de outubro de 2001.

${ }_{25}$ STF, HC 73662/MG, Segunda Turma, Relator Ministro Marco Aurélio, julgado em 21 de maio de1996. 
afastamento da presunção absoluta de violência ou grave ameaça nos casos de relações sexuais com menores de 14 anos.

Não há dúvida de que o Estado tem legitimidade para interferir em qualquer caso de vulnerabilidade, mas é preciso sempre ter em mente a necessidade de critérios que limitem os processos de criminalização desenvolvidos a partir de tal técnica. E, nesse caminho, é de se observar que a relação de exploração implica vantagem injusta que envolve algum tipo de defeito no processo pelo qual o resultado indevido foi atingido. ${ }^{26} \mathrm{O}$ mais forte aproveita-se da fragilidade de alguém para obter vantagem injusta sobre a fraqueza alheia. Entretanto, as proibições não podem ser a regra e, sempre que possível, o intérprete deve atender ao caso concreto, sem generalizações.

\subsubsection{Vulnerabilidade socioeconômica}

Por outro lado, se a conduta de um determinado indivíduo não afeta a terceiros, a intervenção sem sua liberdade somente se legitima por causa devido à sua condição de vulnerabilidade. Isso porque, em tese, quem não é vulnerável não precisa nem solicita a proteção do Estado, de modo que o princípio paternalista considera que o vulnerável, devido à sua posição de mais fraco, é merecedor de se tornar destinatário da proteção da norma. A intervenção do direito penal fundada numa restrição paternalista, portanto, apenas se legitima se tiver como objeto pessoa vulnerável, fragilizada. No entanto, o conceito de vulnerabilidade é amplo e vai além do sentido que lhe atribui o direito. Entende-se por vulneráveis aqueles indivíduos que podem ser atacados ou ofendidos, ${ }^{27}$ ou seja, "são pessoas que por condições sociais, culturais, étnicas, políticas, econômicas, educacionais e de saúde têm as diferenças, estabelecidas entre eles e a sociedade envolvente,

26 WERTHEIMER, Alan. Exploitation. In: Stanford Encyclopedia of Philosophy. Disponível em: <http://plato.stanford.edu/entries/exploitation/>. Acesso em: 17 jun. 2010.

${ }^{27}$ DICIONÁRIO MICHAELIS ONLINE. Disponível em: $<$ http://www.michaelis.uol.com.br>. Acesso em: 20 fev. 2010. 
transformadas em desigualdade". ${ }^{28}$ Assim, a vulnerabilidade é compreendida como indicador de desequilíbrio nas relações pessoais, o que implica em tornar necessária a interferência externa para que o equilíbrio seja estabelecido. Assim, o paternalista se julga capaz de buscar o equilíbrio necessário e proteger o vulnerável em suas próprias relações.

A vulnerabilidade pode ser concebida sob dois pontos de vista: um primeiro, moral, e um segundo, operacional. Sob o ponto de vista moral, vulnerável é o sujeito desprovido de virtudes, incapaz de cuidar de si mesmo e que, por isso, demanda uma cautela especial. ${ }^{29} \mathrm{E}$, nesse aspecto, a virtude assume o sentido de capacidade interna de autocondução, de modo que existe uma relação de dependência entre vulnerável e outra pessoa ou instituição, como o Estado, por exemplo. Já sob o ponto de vista operacional, vulnerabilidade é a "falta não deliberada de condições pessoais ou ambientais para o viver como sujeitos humanos". 30 Aqui, o vulnerável é compreendido como a pessoa a quem se deve dar maior atenção para que ela viva uma vida mais digna, uma vez que sua fragilidade a impede de, por conta própria, tornar isso possível.

A vulnerabilidade, portanto, tem estrita ligação com a forma de vida do indivíduo. Assim, as condições sociais podem tornar as pessoas mais ou menos vulneráveis a certos riscos, o que significa que a vulnerabilidade social deve ser entendida como a "falta de ativos materiais e imateriais a que determinado indivíduo ou grupo está exposto a sofrer futuramente alterações bruscas e significativas em seus níveis de vida". ${ }^{31}$ Por isso, a vulnerabilidade social pode se manifestar em dois planos: estrutural e

${ }^{28}$ GUIMARÃES, Maria Carolina S., NOVAES, Sylvia Caiuby. Vulneráveis. Portal da Bioética da Universidade Federal do Rio Grande do Sul. Disponível em <http://www.ufrgs.br/bioetica/vulnera.htm>. Acesso em: 08 fev. 2010.

${ }^{29}$ READER, Soran. New Directions in Ethics: Naturalisms, Reasons and Virtue. Ethical Theory and Moral Practice, Amsterdan, vol. 3, n. ${ }^{\circ}$ 04, dez. 2000. p. 346.

30 ANJOS, Marcio Fabri dos. A vulnerabilidade como parceira da autonomia. Revista da Sociedade Brasileira de Bioética, Brasília, DF, vol. 02, n. ${ }^{\circ}$ 02, 2006. p. 181.

31 SILVA, Algéria Valéria da. Vulnerabilidade social e suas consequências: o contexto educacional da juventude na região metropolitana de Natal. In: 13..$^{\circ}$ ENCONTRO DE CIÊNCIAS SOCIAIS DO NORTE NORDESTE, Maceió, 2007. [s.p.]. 
subjetivo. No plano estrutural, pode ser dada por uma mobilidade descendente e, no plano subjetivo, pelo desenvolvimento de sentimentos de incerteza, insegurança, de não-pertencimento a determinado grupo, de fragilidade dos atores. ${ }^{32}$

A existência de uma condição de vulnerabilidade leva a situações de desequilíbrio verificadas especialmente nas relações em que as diferenças são determinantes para o efeito obtido pelo negócio. Assim, quem tem mais a oferecer consegue, com maior facilidade, um resultado vantajoso, pois é mais fácil obter de um sujeito em condições precárias de subsistência seu consentimento a que sejam praticados comportamentos com os quais não concorda. E, para tanto, não é preciso qualquer tipo de coerção moral ou física, pois a pessoa, devido à sua condição de vulnerabilidade, aceita propostas contrárias ao seu desejo ou à sua consciência. Para evitar isso, o direito, dentro do contexto social e em algumas hipóteses, interfere nas relações em busca do equilíbrio.

32 Ibidem. [s.p.]. 
No Brasil, o ordenamento jurídico também prevê normas que reconhecem a vulnerabilidade de certas categorias de pessoas e lhes destinam alguma forma de proteção, como a inversão do ônus da prova e o domicílio do consumidor como foro para conflitos envolvendo relações de consumo; nulidade de atos praticados por absolutamente incapazes. Nesses casos, a relação de desigualdade pode manifestar-se individual ou coletivamente, entre indivíduos, entre diferentes grupos, culturas ou etnias minoritárias em relação a um grupo mais amplo, ${ }^{33}$ o que é a principal diferença destacada por alguns entre vulnerabilidade e ausência de autonomia, já que a última é pessoal e individual, e não pode ser atribuída a grupos ou entidades. $^{34}$ Todavia, prevalece a opinião de que vulnerabilidade é uma das formas da ausência de autonomia, seja de um indivíduo ou de um grupo determinado de pessoas. Por sua vez, a Resolução 196, de 1996, do Conselho Nacional de Saúde, em seu item II.15, afirma que vulnerabilidade "refere-se a estado de pessoas ou grupos, que por quaisquer razões ou motivos, tenham a sua capacidade de autodeterminação reduzida, sobretudo no que se refere ao consentimento livre e esclarecido". Tal definição toca às experiências e pesquisas envolvendo seres humanos, que precisam de consentimento válido para seu prosseguimento, mas também se aplica às relações entre médicos e pacientes nos casos de escolhas de tratamentos conforme a situação de saúde, quando o doente pode optar por algo que the seja mais interessante, inclusive a própria interrupção dos cuidados.

O Supremo Tribunal Federal empregou argumentos relacionados à vulnerabilidade social e econômica ao julgar, no âmbito da Ação Declaratória de Constitucionalidade, plenamente constitucional o artigo 41da Lei 11.340/2006, a chamada Lei Maria da Penha, que afasta, nos crimes de violência doméstica contra a mulher, os benefícios previstos na

33 GUIMARÃES, Maria Carolina S.; NOVAES, Sylvia Caiuby. Autonomia reduzida e vulnerabilidade: liberdade de decisão, diferença e desiguldade. Revista Bioética, Brasília, DF, vol. 07, n. ${ }^{\circ}$ 01, 1999. p. 22. ANJOS, Marcio Fabri dos. op. cit. p. 181.

${ }^{34}$ ANJOS, Marcio Fabri dos. op. cit. p. 177. 
Lei n. 9.099/95. ${ }^{35}$ No voto condutor do julgamento, o relator, Ministro MARCO AURÉLIO, reconheceu que "para frear a violência doméstica, não se revela desproporcional ou ilegítimo o uso do sexo como critério de diferenciação. A mulher é eminentemente vulnerável quando se trata de constrangimentos físicos, morais e psicológicos sofridos em âmbito privado. Não há dúvida sobre o histórico de discriminação e sujeição por ela enfrentado na esfera afetiva. As agressões sofridas são significativamente maiores do que as que acontecem contra homens em situação similar. Além disso, mesmo quando homens, eventualmente, sofrem violência doméstica, a prática não decorre de fatores culturais e sociais e da usual diferença de força física entre os gêneros." ${ }^{36}$ Argumentos semelhantes também foram utilizados no julgamento da Ação Direta de Inconstitucionalidade 4424/DF, que decidiu que "a ação penal relativa a lesão corporal resultante de violência doméstica contra a mulher é pública incondicionada". ${ }^{37} \mathrm{Na}$ ocasião, o relator, também o Ministro MARCO AURÉLIO, afirmou que "deixar a cargo da mulher autora da representação a decisão sobre o início da persecução penal significa desconsiderar o temor, a pressão psicológica e econômica, as ameaças sofridas, bem como a assimetria de poder decorrente de relações histórico-culturais, tudo a contribuir para a diminuição de sua proteção e a prorrogação da situação de violência, discriminação e ofensa à dignidade humana. Implica relevar os graves impactos emocionais impostos pela violência de gênero à vítima, o que a impede de romper com o estado de submissão." ${ }^{38}$

Assim, para o Supremo Tribunal Federal, não há dúvida de que a mera condição de mulher já determina uma vulnerabilidade social e, em muitos casos, também econômica. No entanto, diversos fatores, analisados de maneira isolada ou conjunta, podem levar à vulnerabilidade de alguém.

\footnotetext{
35 STF, ADC 19/DF, Tribunal Pleno, relator Ministro Marco Aurélio, julgado em 09 de fevereiro de 2012.

${ }^{36}$ STF, ADC 19/DF, voto do Ministro Relator Marco Aurélio, p. 14 e 15 do Inteiro Teor do Acórdão.

${ }^{37}$ STF, ADI 4.424/DF, Tribunal Pleno, relator Ministro Marco Aurélio, julgado em 09 de fevereiro de 2012.

${ }^{38}$ STF, ADI 4.424/DF, voto do Ministro Relator Marco Aurélio, p. 12 do Inteiro Teor do Acórdão.
} 
O menor desenvolvimento intelectual e cultural pode determinar certas fragilidades no momento de se decidir algo, ${ }^{39}$ bem como a falta de desenvolvimento emocional também pode ser determinante para tornar uma pessoa vulnerável, assim como a pouca idade. ${ }^{40} \mathrm{E}$, também, há ampla aceitação a tese de que o baixo nível sócio-econômico também é fator de risco no aumento de stress e, consequentemente, da vulnerabilidade. ${ }^{41}$ Por outro lado, o rol de pessoas vulneráveis não é taxativo, de modo que a lei, de forma geral, determina a vulnerabilidade de menores de idade e pessoas com problemas mentais (desenvolvimento mental incompleto ou retardado), que são denominadas, pelo direito civil, como incapazes e, pelo direito penal, como inimputáveis. Existe, além disso, um terceiro grande grupo de sujeitos expostos a situações de risco mesmo apresentando idade superior aos 18 anos e saúde mental sem comprometimento, que é o de pessoas que eventualmente encontram-se perturbadas por algum motivo e, especificamente, em momento determinado, podem agir influenciadas pela vulnerabilidade momentânea. Contudo, quando há referência a menores e a adultos com problemas mentais, necessariamente, é exigido um comportamento de alguém para compensar sua vulnerabilidade, como a lei determina em diversas circunstâncias (por exemplo, a nomeação de tutores e curadores para a prática de atos civis). E nada impede, também, que as pessoas inseridas no terceiro grupo de vulneráveis possam ter o auxílio de outrem a fim de compensar suas dificuldades de agir.

39 ZANER, Richard M. The Phenomenon of Vulnerability in Clinical Encounters. Human Studies, Holanda, vol. 29, n. ${ }^{\text {3 }}$, set. 2006. pp. 284 e ss.

40 HUTZ, Claudio S., KOLLER, Silvia H., BANDEIRA, Denise R. Resiliência e vulnerabilidade em crianças em situação de risco. In: KOLLER, Silvia Helena. Coletâneas da Associação Nacional de Pesquisa e Pós-graduação em Psicologia, Rio de Janeiro, n. ${ }^{\circ}$ 12, 1996. p. 80. 41 CASTRO, Mary Garcia; ABRAMOVAY, Miriam. Jovens em situação de pobreza, vulnerabilidades sociais e violências. Cadernos de Pesquisa da Fundação Carlos Chagas, São Paulo, n. 116, jul. 2002. pp. 143 e ss. 


\subsubsection{Bens indisponíveis?}

Há uma tradição na doutrina e na jurisprudência brasileira de considerar a existência de bens jurídicos indisponíveis, aqueles dos quais seu titular não pode dispor sob fundamento de que a condição de inalienabilidade é inerente à existência da própria pessoa. ${ }^{42} \mathrm{Um}$ bem é considerado indisponível quando for essencial à natureza humana e constituir condição de vida humana digna, ademais são interesses que, embora referidos ao indivíduo, importam à espécie humana como um todo de forma que, lhes negar o valor, sempre afetará à humanidade em sua totalidade. $^{43}$

O Supremo Tribunal Federal reconheceu a característica de indisponibilidade de determinados bens, por exemplo, no julgamento do Recurso Extraordinário 248.869/SP, em que se discutiu a legitimidade ativa do Ministério Público para ajuizar ação de investigação de paternidade. $\mathrm{Na}$ ocasião, sua Segunda Turma utilizou o argumento da indisponibilidade para afirmar que "a Carta Federal outorgou ao Ministério Público a incumbência de promover a defesa dos interesses individuais indisponíveis, podendo, para tanto, exercer outras atribuições prescritas em lei, desde que compatível com sua finalidade institucional (CF, artigos 127 e 129). 3. O direito ao nome insere-se no conceito de dignidade da pessoa humana e traduz a sua identidade, a origem de sua ancestralidade, o reconhecimento da família, razão pela qual o estado de filiação é direito indisponível, em função do bem comum maior a proteger, derivado da própria força impositiva dos preceitos de ordem pública que regulam a matéria (Estatuto da Criança e do Adolescente, artigo 27). 4. A Lei 8560/92 expressamente assegurou ao Parquet, desde que provocado pelo interessado e diante de evidências positivas, a possibilidade de intentar a ação de investigação de paternidade, legitimação essa decorrente da proteção constitucional conferida à família e

\footnotetext{
${ }^{42}$ O'MANIQUE, John. Universal and inalienable rights: a search for foundations. Human Rights Quarterly, Baltimore, vol. 12, n. ${ }^{\circ}$ 4, pp. 465-485, nov. 1990. p. 467.

43 MINAHIM, Maria Auxiliadora. O consentimento do ofendido em face dos bens jurídicos indisponíveis. Revista de Ciências Jurídicas, Belo Horizonte, vol. 06, n. ${ }^{\circ}$ 01, jan./jun. 2008. pp. 227-228.
} 
à criança, bem como da indisponibilidade legalmente atribuída ao reconhecimento do estado de filiação. Dele decorrem direitos da personalidade e de caráter patrimonial que determinam e justificam a necessária atuação do Ministério Público para assegurar a sua efetividade, sempre em defesa da criança, na hipótese de não reconhecimento voluntário da paternidade ou recusa do suposto pai. 5. O direito à intimidade não pode consagrar a irresponsabilidade paterna, de forma a inviabilizar a imposição ao pai biológico dos deveres resultantes de uma conduta volitiva e passível de gerar vínculos familiares. Essa garantia encontra limite no direito da criança e do Estado em ver reconhecida, se for o caso, a paternidade. 6. O princípio da necessária intervenção do advogado não é absoluto (CF, artigo 133), dado que a Carta Federal faculta a possibilidade excepcional da lei outorgar o jus postulandi a outras pessoas. Ademais, a substituição processual extraordinária do Ministério Público é legítima (CF, artigo 129; CPC, artigo 81; Lei 8560/92, artigo 2o, \ 4o) e socialmente relevante na defesa dos economicamente pobres, especialmente pela precariedade da assistência jurídica prestada pelas defensorias públicas. 7. Caráter personalíssimo do direito assegurado pela iniciativa da mãe em procurar o Ministério Público visando a propositura da ação. Legitimação excepcional que depende de provocação por quem de direito, como ocorreu no caso concreto. Recurso extraordinário conhecido e provido." 44

No voto que orientou a decisão, o relator, Ministro MAURÍCIO CORRÊEA, referiu que "a indisponibilidade de determinados direitos não decorre da natureza privada ou pública das relações jurídicas que lhes são subjacentes, mas da importâncias que elas têm para a sociedade. O interesse público de que se cogita é aquele relacionado à preservação do bem comum, da estabilidade das relações sociais, e não o interesse da administração pública em sentido estrito. Daí reconhecer-se ao Estado não só o direito, mas o dever, de tutelar essas garantias, pois embora guardem natureza pessoal imediata, revelam, do ponto de vista mediato, questões de ordem pública. Direito individual indisponível é aquele que a sociedade, por meio de seus representantes, reputa como essencial à consecução da paz social,

\footnotetext{
${ }^{44}$ STF, RE 248869/SP, Segunda Turma, Relator Ministro Maurício Côrrea, julgado em 07
} de agosto de 2003. 
segundo os anseios da comunidade, transmudando, por lei, sua natureza primária marcadamente pessoal. À partir de então dele não pode dispor seu titular, em favor do bem comum maior a proteger, pois gravado de ordem pública sobrejacente, ou no dizer de Ruggiero "pela utilidade universal da comunidade." ${ }^{* 5}$

Contudo, quando se tem em vista o sujeito autônomo, é possível enxergar duas vertentes: respeitar totalmente sua liberdade de dispor de bens jurídicos, quaisquer que sejam estes, ou restringir essa liberdade para a preservação dos bens considerados indisponíveis. E aqui também surge uma indagação difícil, mas fundamental: a autonomia individual permite ao sujeito abrir mão de sua condição de autônomo? É possível alguém usar sua autonomia para escolher deixar de ser autônomo, por exemplo, ao aceitar um contrato de escravidão voluntária e se tornar propriedade de alguém? Embora tal resposta mereça um estudo só para ela, aqui se adianta que a esta só pode ser negativa, pois o Estado liberal não deve permitir a ninguém abrir mão de sua autonomia para se tornar um sujeito controlado no futuro, bem como não se pode relativizar certos preceitos, ainda que tais vedações signifiquem atingir a liberdade atual do indivíduo. Nesse ponto, o importante é preservar a autonomia para o futuro como meio de se manter o próprio Estado liberal, pois, como defende Mill, a escravidão, mesmo a voluntária, não pode ser permitida por significar a colocação em risco do próprio Estado de direito. A liberdade, explica STUART MILL, é um valor fundamental e, por isso, ninguém pode utilizar a própria autonomia para escolher voluntariamente a restrição da própria liberdade em favor da perda do controle sobre si. $^{46}$

Isso significa que um bem jurídico apenas pode ser considerado indisponível nas hipóteses em que sua ausência impedir o exercício da autonomia individual. No entanto, isso não quer dizer que a indisponibilidade do bem, com a finalidade de proteger a autonomia, pode ser interpretada amplamente. As possíveis consequências à autonomia da pessoa devem se realizar de maneira imediata à lesão ao bem jurídico, pois

\footnotetext{
45 STF, RE 248869/SP, voto do Ministro Relator Maurício Corrêa, às fls. 781.

46 BRINK, David O. Mill's Deliberative Utilitarianism. Philosophy and Public Affairs, vol. 21, n. ${ }^{\circ} 01$, pp. 67-103, 1992. p. 70.
} 
não é legitima uma norma penal com fundamento em efeitos meramente remotos, como era o caso, por exemplo, do revogado delito de adultério, que era entendido como uma ofensa aos bons costumes, à estrutura familiar ou à dignidade do cônjuge traído, ${ }^{47}$ consequências insuficientes para que a infidelidade conjugal se tornasse uma conduta penalmente proibida.

Assim, é possível concluir que bens indisponíveis são aqueles cuja violação gera a imediata perda da autonomia individual. Isso porque a perda da autonomia não pode ser vislumbrada somente a partir dos valores do observador externo, mas de considerações do sujeito que sofre a restrição e da importância que o bem jurídico tutelado tem para seu modo de vida autônomo, de acordo com a concepção histórica de autonomia. Por isso, não há que se falar em bens absolutamente indisponíveis, mas reconhecer que a indisponibilidade varia de acordo com a autonomia individual em seu conceito histórico.

\subsection{Finalidade da norma paternalista}

O conceito de paternalismo engloba aquilo que se pretende com a restrição da liberdade individual. Pode-se afirmar que uma medida paternalista pode buscar a promoção de um bem ou a evitação de um mal. Uma norma que obriga o trabalhador a contribuir mensalmente com a Previdência Social pretende que este cidadão tenha, no futuro, uma aposentadoria que lhe promova um mínimo de dignidade, ou seja, um benefício. Por outro lado, obrigar o motorista a usar cinto de segurança é medida que pretende diminuir os danos de eventual acidente automobilístico. O direito penal do Estado Democrático de Direito somente possui legitimidade para evitar danos aos bens jurídicos, por isso não está autorizado a promover benefícios.

Dentro do conceito de autonomia, segundo FEINBERG, dano é um passo de um nível de satisfação de interesses para outro nível inferior de satisfação de interesses. Assim, evitar um dano é impedir que alguém

\footnotetext{
${ }^{47}$ HUNGRIA, Nelson, LACERDA, Romão Cortes de, FRAGOSO, Heleno Cláudio. op. cit. p. 370 .
} 
passe de um nível de satisfação para outro inferior. Promover um benefício, por outro lado, é provocar um passo adiante, de um nível para outro superior de satisfação. ${ }^{48} \mathrm{~A}$ importância desse conceito reside nas considerações dos valores individuais de cada titular de bem jurídico e não em valores pré-estabelecidos por terceiro. Desse modo, um comportamento que pode ter um caráter lesivo para uma pessoa pode não ter para outra. Como exemplo, podemos entender que cortar o cabelo pode ser danoso a um calouro da faculdade, porém, outro calouro considera o fato um ritual saudável de recepção.

A criminalização de condutas para promoção de um bem é a oportunidade de impor valores morais à comunidade, o que vai de encontro aos princípios do Estado Democrático de Direito. Nas linhas de SANTIAGO NINO ${ }^{49}$, "a imposição de valores que presumidamente são os mais adequados à pessoa que sofre a restrição da liberdade deixa de ser paternalismo para assumir a feição do perfeccionismo". O Estado perfeccionista quer moldar o cidadão de acordo com aquilo que entende ser o melhor, contra sua vontade, proibindo-o de certas escolhas com a finalidade de promover-lhe valores que até então eram desconhecidos ou recusados. Por isso, correta é a posição de ALEMANY, que define a atuação do Estado na finalidade de evitar danos físicos, psíquicos e econômicos à outra parte da relação paternalista. ${ }^{50}$ Ficam de fora os meros incômodos e os atos meramente imorais que, apesar de não serem socialmente tolerados, não são suficientemente perigosos ou lesivos.

\section{AS VERTENTES DO PATERNALISMO}

Uma vez conceituado o paternalismo, é preciso analisar suas vertentes para compreender a essência de algumas normas penais consideradas paternalistas e afirmar, ou não, sua legitimidade. O conceito

\footnotetext{
${ }^{48}$ FEINBERG, Joel. Harm to others. Nova Iorque: Oxford. 1984. pp. 50 e ss.

49 SANTIAGO NINO, Carlos. Ética e derechos humanos. Buenos Aires: Astrea. 2007. pp. 140 e ss.

${ }^{50}$ ALEMANY, Macario. op. cit. pp. 381 e ss.
} 
de paternalismo aqui adotado permite algumas variações conforme o modo como é aplicado e sua abrangência. A importância de reconhecer as diferenças conceituais é evitar a adoção plena ou a negação total do paternalismo e, consequentemente, a intervenção exacerbada na liberdade individual ou a falta de proteção a bens jurídicos que reclamam a interferência do Estado. Isso quer dizer que há situações intermediárias nas quais normas paternalistas são legítimas.

Em primeiro lugar, as condições do titular do bem jurídico devem ser consideradas, pois nem sempre há autonomia para decisões referentes a eventuais lesões. FEINBERG faz a distinção entre paternalismo rígido ( hard) e moderado (soft). O paternalismo rígido aceita como fundamento de uma intervenção penal a necessidade de proteger adultos autônomos contra sua própria vontade, quando houver consequências danosas a si mesmos, apesar da vontade completamente livre ${ }^{51}$; o paternalismo moderado defende o direito de o Estado prevenir condutas lesivas consentidas apenas quando não houver voluntariedade da pessoa prejudicada ou quando a intervenção for temporariamente necessária para determinar se a vontade é livre ou não. ${ }^{52}$ FEINBERG questiona se o paternalismo moderado deveria ser realmente considerado um tipo de paternalismo ou um princípio antipaternalista. Para o autor, o paternalismo moderado não é uma espécie de paternalismo por completo, pois, na verdade, poder-se-ia usar o rótulo "anti-paternalismo" moderado, uma vez que o direito penal pode ser aceito de forma paternalista dentro de limites. ${ }^{53} \mathrm{O}$ paternalismo moderado é um princípio de restrição da liberdade que se legitima quando se quer proteger a pessoa de comportamentos externos lesivos e involuntários. Ele somente justifica o paternalismo nas hipóteses em que é necessário determinar se a pessoa a ser atingida está agindo voluntária e conscientemente. Assim, a intervenção paternalista se justifica nas hipóteses em que não é possível determinar ou comprovar a capacidade do indivíduo. Assim, por exemplo, autolesões quando praticadas por crianças, doentes mentais ou adultos com perturbações mentais temporárias, negócios

\footnotetext{
${ }^{51}$ FEINBERG, Joel. op. cit. p. 12.

${ }^{52}$ FEINBERG, Joel. op. cit. p. 12.

${ }^{53}$ FEINBERG, Joel. op. cit. p. 13.
} 
celebrados por sujeito incapaz nos casos em que há algum tipo de prejuízo fora de sua consciência.

Outra distinção importante leva em consideração as pessoas atingidas pela restrição da liberdade e aquelas que se pretende proteger. Quando há coincidência entre as pessoas que sofrem a restrição da liberdade e as que se pretende proteger costuma-se denominar paternalismo direto. Porém, há situações de paternalismo indireto, nas quais as medidas restritivas alcançam indivíduos além daqueles que se quer proteger. No direito penal as normas indiretamente paternalistas são comuns, por exemplo, os tipos penais de lenocínio, que criminalizam as condutas do rufião para proteger a pessoa sexualmente explorada. Há quem entenda, com certa razão, que o paternalismo indireto não é um "paternalismo legítimo", pois suas restrições incidem em questões referentes a lesões a terceiros (harm to others), não a "lesões a si mesmo" (harm to self)..$^{54}$

De fato, o paternalismo indireto só é paternalismo propriamente dito quando implicar restrição na liberdade de quem consente em heterolesões ao bem jurídico do qual é titular. São as situações nas quais terceiros expõem a perigo ou lesionam bem jurídico com o consentimento do seu titular. Alguns exemplos podem ser destacados: o tatuador que provoca lesões no cliente, o adulto que pratica o sadomasoquismo, o pai que prefere morrer para doar um órgão para salvar a vida de seu filho, o religioso que rejeita a transfusão de sangue e assume o risco de morte por causa de sua crença. Proibir esses comportamentos contra a vontade do titular do bem jurídico é uma medida paternalista. Quando não há consentimento válido não há que se falar em paternalismo. Para ilustrar, basta analisar o tipo penal do furto. A lei restringe a liberdade individual quando proíbe alguém de subtrair coisa alheia móvel contra a vontade do titular do bem. Isso não é paternalismo, pois o titular do bem quer e aprova a tutela de seu patrimônio pela lei penal.

Uma vez conceituado o paternalismo direto como a coincidência entre as pessoas que sofrem restrição da liberdade e as que se quer proteger

\footnotetext{
${ }^{54}$ SZERLETICS, Antal. Paternalism. Essex Autonomy Project Green Paper Report. Londres: University of Essex. 2011. Disponível em: $\square<$ http://autonomy.essex.ac.uk>. Acesso em: $10 / 06 / 2014$.
} 
de um dano, fundamental tecer alguns comentários sobre o bem jurídico a ser tutelado para evitar pretextos falaciosos de criminalização exacerbada. O principal exemplo é o art. 28 da Lei 11.343/2006 (Lei de Drogas). Segundo o artigo, é crime "adquirir, guardar, tiver em depósito, transportar ou trouxer consigo, para consumo pessoal, drogas sem autorização ou em desacordo com determinação legal ou regulamentar". A doutrina majoritária considera que a norma tutela a "saúde pública", sem muito aprofundamento. Não obstante, a discussão não pode ficar alheia à liberdade individual do usuário.

O tipo penal descreve um comportamento que não ultrapassa a esfera privada do sujeito que faz uso da droga. Importante destacar que o tipo descreve um crime formal, ou seja, basta praticar qualquer verbo com 0 fim de consumir; não há necessidade sequer de consumo. O uso da droga é mero post factum impunível que pouco interessa à consumação do crime. Também não há qualquer menção nas elementares sobre atos lesivos praticados após o consumo de droga (por exemplo, provocar lesão corporal sob efeito da droga). Quando houver resultado lesivo a terceiro, resultado do consumo da droga, o sujeito responde pelo tipo penal respectivo (lesão corporal, homicídio, dano) com a possibilidade de aumento da pena.

No âmbito do Tribunal de Justiça do Estado de São Paulo já existiu a manifestação de que "o art. 28 da Lei n. 11.343/2006 é inconstitucional. A criminalização primária do porte de entorpecentes para uso próprio é de indisfarçável insustentabilidade jurídico-penal, porque não há tipificação de conduta hábil a produzir lesão que invada os limites da alteridade, afronta os princípios da igualdade, da inviolabilidade da intimidade e da vida privada e do respeito à diferença, corolário do principio da dignidade, albergados pela Constituição Federal e por tratados internacionais de Direitos Humanos ratificados pelo Brasil". ${ }^{55}$ Tal decisão ressalta que o uso de drogas é algo que diz respeito apenas à saúde do usuário, não passa de uma autolesão e, por isso, não pode ser objeto de criminalização.

Já no Supremo Tribunal Federal ${ }^{56}$, a questão está sendo discutida no âmbito do Recurso Extraordinário 635659, cujo julgamento está suspenso

\footnotetext{
55 Processo nº 01113563.3/0-0000-000, julgamento em 31 de março de 2008.

56 Até o dia 10/11/2016, data da entrega do presente trabalho aos coordenadores da obra, o julgamento ainda não havia sido reiniciado.
} 
devido ao pedido de vista do Ministro TEORI ZAVASCKI. Até o momento, o relator, Ministro GILMAR MENDES, apresentou seu voto no sentido de declarar a inconstitucionalidade do artigo 28 da Lei de Drogas, acompanhado dos ministros ROBERTO BARROSO e EDSON FACHIN, que, no entanto, restringiram seu voto ao porte de maconha. O Ministro ROBERTO BARROSO, aliás, também propôs que o porte de até 25 gramas de maconha ou a plantação de até seis plantas fêmeas como parâmetros de referência para diferenciar consumo e tráfico até que o Congresso Nacional regulamentasse a matéria. ${ }^{57}$

\section{LEGITIMIDADE DE NORMAS PATERNALISTAS}

As normas paternalistas não podem ser afastadas por ilegitimidade apenas por serem assim classificadas. Deve-se delimitar as situações em que o Estado pode interferir na liberdade individual e fundamentar essas intervenções de maneira a restringir os processos de criminalização e não extrapolar as funções do direito penal no Estado Democrático de Direito. Para tanto, não se pode ir atrás de uma única e simplista regra, pois são várias as complicações e não se permite incorrer nos mesmos equívocos tradicionais de nossa jurisprudência.

\subsection{Ausência de autonomia}

A ausência de autonomia é fundamento que legitima a intervenção paternalista. O sujeito que não pode decidir sobre assuntos que dizem respeito a si próprio requer proteção estatal. No entanto, em relação às normas penais, a intervenção só pode buscar a evitação de um dano ou de uma situação perigosa. Para promover um bem ao indivíduo a norma penal não é instrumento adequado por obediência aos princípios do Direito Penal, 
especialmente a subsidiariedade. Duas são as hipóteses que autorizam o Estado a passar por cima da vontade individual: a ausência de discernimento e a falta de conhecimento dos fatos.

O Código Penal prevê o crime de abuso de incapazes, no art. 173, que consiste em "abusar, em proveito próprio ou alheio, de necessidade, paixão ou inexperiência de menor, ou da alienação ou debilidade mental de outrem, induzindo qualquer deles à prática de ato suscetível de produzir efeito jurídico, em prejuízo próprio ou de terceiro". O tipo penal não requer a fraude porque as condições nas quais o agente aproveita-se da vítima que não possui o discernimento necessário para fazer escolhas sem provocar prejuízo a si mesma - são suficientes para afastar a autonomia.

Diferente é o crime de estelionato, em cujo tipo penal a fraude é elementar porque a escolha da vítima é baseada na falta de conhecimento dos fatos. A lei presume que o indivíduo teria feito escolha diversa caso tivesse a consciência das circunstâncias fáticas que lhe foram omitidas ou alteradas. O autor faz uso de "malicioso subterfúgio para alcançar um fim ilícito" 58 por meio de vontade viciada da vítima.

\subsection{Bens coletivos}

O Supremo Tribunal Federal, em julgamento realizado por sua Primeira Turma, no âmbito do Habeas Corpus 104.467, afirmou que "No crime de manter casa de prostituição, imputado aos Pacientes, os bens jurídicos protegidos são a moralidade sexual e os bons costumes, valores de elevada importância social a serem resguardados pelo Direito Penal, não havendo que se falar em aplicação do princípio da fragmentariedade." ${ }^{\prime 9} \mathrm{O}$ voto condutor do julgamento, proferido pela Ministra Relatora CARMEN LUCIA, justificou que "no estabelecimento mantido pelo proxeneta ocorre exploração sexual de pessoas, conduta inadmissível que, portanto merece ser reprimida pelo Direito Penal. Ademais, embora a obtenção de lucro com a prostituição de terceiros não seja elemento objetivo do tipo, trata-se de

\footnotetext{
${ }^{58}$ HUNGRIA, Nelson. Comentários ao Código Penal, vol. VII. Rio de Janeiro: Forense. 1955. p. 164.

${ }^{59}$ STF, HC 104.467/RS, Primeira Turma, Relatora Ministra Cármen Lúcia, julgado em 08 de fevereiro de 2011.
} 
regra nessa espécie de atividade e, inclusive, teria ocorrido no fato concreto imputado aos Pacientes." ${ }^{60}$ Esse julgado foi corretamente criticado por GRECO por não ignorar a inexistência de um bem jurídico "moralidade pública", não considerar que é incompatível com o ideário de um Estado liberal conceber a dignidade ou autodeterminação sexual em moldes perfeccionistas, como algo que pode ser violado pelo próprio titular e não optar pelo caminho de interpretar teleologicamente o conceito de "exploração sexual" previsto no artigo 229 do Código Penal, não no sentido de ser um gênero do qual a prostituição é espécie, mas uma situação em que, por fraude, coação ou com aproveitamento de condições coercitivas é violada a autodeterminação sexual. ${ }^{61}$ Esse julgado demonstra, com o recurso ao suposto bem coletivo "moralidade pública", a dificuldade de se admitir um conceito de bem jurídico em sentido político criminal. E, sob a perspectiva de um paternalismo penal legítimo, tampouco tal conceito de "moralidade pública" conseguiria se sustentar como argumento para justificar a intervenção penal na vida dos cidadãos.

Com efeito, no âmbito de um paternalismo penal moderado, o bem coletivo tem como fundamento um interesse social, considerado como forma ampla de denominar a finalidade da norma penal, que admite diversas classificações de acordo com sua natureza. Nesse sentido, são considerados pontos controvertidos o beneficiário deste interesse, os limites entre o particular e o coletivo e, dentre os particulares, quais dizem respeito unicamente ao sujeito que os detém e aos terceiros que podem estar envolvidos. Assim, o patrimônio de uma pessoa, se for atingido, inicialmente, é problema exclusivamente desta. No entanto, se esta pessoa for provedora de uma família, o alcance das consequências é maior. No mesmo sentido, a vida humana pertence apenas ao seu titular, porém, se o sujeito cometer um suicídio os efeitos do ato atingirão seus familiares, tanto financeiramente quanto emocionalmente. E, a partir desse ponto de vista, os princípios da lesão a terceiros (harm to others) e da autolesão (harm to self) relacionam-se diretamente com os titulares dos interesses protegidos, de

\footnotetext{
${ }^{60}$ STF, HC 104.467/RS, voto da Ministra Relatora Cármen Lúcia, fls. 65.

${ }^{61}$ GRECO, Luís. Casa de prostituição (art. 229 do CP) e direito penal liberal: reflexões por ocasião do recente julgado do STF (HC 104.467). In; Revista Brasileira de Ciências Criminais 92. São Paulo: Editora Revista dos Tribunais, 2011, p. 45.
} 
modo que o grande desafio a ser enfrentado é traçar os limites de aplicação dos princípios nas hipóteses em que atingem indiretamente outras pessoas, além do próprio titular do interesse. Assim, revela-se a necessidade de separar aqueles que são diretamente daqueles que são indiretamente prejudicados com a lesão de um interesse. $\mathrm{O}$ exemplo proposto por DWORKIN no caso do cinto de segurança ilustra a situação: se houver um acidente, o prejuízo direto recai sobre o acidentado que não utilizou o cinto, embora, indiretamente, toda a sociedade termine por pagar as contas do tratamento do acidentado no sistema público de saúde. ${ }^{62} \mathrm{E}$ tal exemplo permite afirmar que também a família e os amigos da vítima terão transtornos (financeiros e emocionais) maiores do que teriam se ela tivesse utilizado o cinto de segurança no momento do acidente.

Por isso, quase sempre é possível vislumbrar a existência de mais de um prejudicado quando alguém sofre uma lesão a interesse próprio. $\mathrm{E}$ mesmo quando alguém pratica o suicídio, a conduta não pode ser resumida à mera eliminação da própria vida, pois é possível ocorrer diversas circunstâncias periféricas: gastos com o funeral, investigação do Estado sobre a real causa da morte, diminuição do rendimento da família, desgaste emocional das pessoas próximas etc. Desse modo, mesmo que a vida humana seja um bem jurídico pertencente exclusivamente ao seu titular, envolve interesses alheios. $\mathrm{O}$ mesmo pode-se afirmar do patrimônio, cuja redução afeta seu titular e todos que dele dependem (família, credores, empregados etc.). Isso leva à ideia de que toda lesão a um interesse atinge tanto seu titular (ou titulares) de maneira direta quanto a outras pessoas de forma indireta. O ponto de controversa, então, surge na justificativa de se incriminar tal prejuízo causado indiretamente, cuja ocorrência, por si só, não apresenta fundamento suficiente para a reprimenda penal. Para tanto, exigese a necessidade de outros critérios de incriminação, já que, se assim não fosse, por exemplo, aquele que mata um artista famoso poderia ser responsabilizado por ter retirado a vida da vítima e, além disso, pela dor provocada em seus fãs, o que seria um absurdo. $\mathrm{O}$ uso do direito penal na resolução de conflitos leva, portanto, à necessidade de limites, que devem ser traçados com parâmetros objetivos e subjetivos dos interesses que se

${ }^{62}$ DWORKIN, Gerald. Paternalism: some second thoughts. p. 122. 
pretendem protegidos pelo direito. E, assim, o bem coletivo "moralidade pública" referido pelo julgamento do HC 104.467/RS não se enquadraria nos interesses justificadores de uma punição criminal.

Por outro lado, também é preciso rigor ao se reconhecer interesses sociais justificadores da intervenção penal, pois ao se apresentarem na forma de bens de natureza difusa, que expressam um interesse social legítimo, adquirem, também, a condição de bens inalienáveis. Isso porque, de maneira individual, ninguém pode desistir da proteção de algo que não lhe pertence com exclusividade. Tais bens pertencem igualmente a todas as pessoas e, portanto, individualmente e isso torna impossível que alguém emita um consentimento válido capaz de permitir sua lesão. E, de fato, além de os bens difusos não pertencerem a pessoas ou grupos determinados, não é possível obter a plena autorização de todos os seus titulares para que o bem seja violado.

\subsection{Ponderação de valores}

Outra importante questão que surge na discussão sobre a tutela penal dos interesses é sobre qual o parâmetro que deve ser seguido para determinar sua importância. Isso porque é de se indagar se o que é bom para uma pessoa deve ser determinado por ela mesma ou por terceiros observadores. E, diante desse problema, surgem duas posições distintas: os enfoques objetivo e subjetivo do bem estar. Para os subjetivistas, que em regra são pensadores liberais, o sujeito autônomo sabe o que é melhor para si mesmo de acordo com suas preferências, ${ }^{63}$ pois ninguém melhor do que a própria pessoa para determinar os rumos de sua vida conforme as preferências pessoais. O Estado, assim, deve respeitar suas vontades para preservar sua autonomia pessoal, uma vez que, em sentido contrário, se não houver autonomia suficiente, não há que se falar em respeito à vontade de quem se encontra em situação de vulnerabilidade e, portanto, estaria legitimada a intervenção do Estado. Já os objetivistas, por sua vez, defendem a existência de valores pré-estabelecidos fundamentais à

${ }^{63}$ SCANLON, T. M. Preference and urgency. The Journal of Philosophy, Oxford, vol. 72, n. ${ }^{\circ}$ 19, 1975. pp. 655 e ss. 
configuração do bem-estar social, de modo que o que é bom ao indivíduo é objetivamente identificável e, portanto, há razões para imposições contra suas decisões e preferências. ${ }^{64}$ No entanto, diante da incompatibilidade entre as preferências individuais e os valores determinados como bons, estes devem prevalecer porque, na ausência destes, o bem estar social restaria comprometido. É possível, ainda, estabelecer uma hierarquia entre os interesses centrais e os periféricos para a vida humana para reforçar a legitimidade de intervenção nas escolhas do sujeito. ${ }^{65}$

Todavia, ainda é possível vislumbrar uma terceira corrente, de índole liberal, que busca a harmonia entre os parâmetros subjetivos e objetivos dos interesses para determinar os limites de intervenção do Estado. De acordo com esse entendimento, é preciso preservar alguns interesses objetivamente auferidos como essenciais ao bem estar, ao mesmo tempo em que se respeita a autonomia da pessoa. A ideia central deste ponto de vista é que o valor objetivo da autonomia requer respeito às preferências subjetivas do indivíduo desde que estas não sejam contrárias aos valores objetivos estabelecidos, ${ }^{66}$ o que leva à necessidade de uma base moral objetiva capaz de permitir o exercício das preferências subjetivas individuais sem comprometer o bem estar social e, assim, evitar-se-iam situações extremas como todo tipo de proibição ou liberalidades que resultem em danos irreversíveis. ${ }^{67}$

Tais considerações são de fundamental importância para a teoria do paternalismo penal, pois, ao se adotar uma teoria objetivista, necessariamente deve-se considerar a existência de bens jurídicos indisponíveis para os quais qualquer tipo de consentimento seria inválido. Por outro lado, uma posição subjetivista pura levaria à conclusão de que nenhum bem seria indisponível e, portanto, a pessoa autônoma poderia abrir mão de qualquer bem do qual seja titular, inclusive a própria vida, em qualquer situação. Entretanto, uma posição intermediária (a terceira via)

${ }^{64}$ NINO, Carlos Santiago. op. cit. p. 211.

65 SCANLON, T. M. op. cit. p. 660.

66 NINO, Carlos Santiago. op. cit. p. 217.

${ }^{67}$ SCANLON, T. M., DANCY, Jonathan. Proceedings of the Aristotelian Society, Londres, Vol. 74, 2000. pp. 319-338. 
consideraria a existência de bens jurídicos indisponíveis e outros disponíveis por seu titular quando dotado de autonomia necessária.

Por outro lado, na discussão do paternalismo penal, a distinção entre bens disponíveis e indisponíveis é importante para o estudo da diferença entre paternalismo rígido (ou forte) e paternalismo flexível (ou brando). Se o bem atingido for indisponível, o paternalismo rígido sempre será justificável, pois ninguém poderá dispor dele. Mas, caso o bem seja disponível, somente será legítima a intervenção quando seu titular não possuir autonomia suficiente. Assim, se for considerada uma posição puramente objetivista, qualquer forma de paternalismo seria justificável quando o bem fosse indisponível na opinião do terceiro observador (no caso, o Estado).

A posição que parece a mais consistente, no entanto, é a intermediária, dentro de uma concepção liberal de direito. Isso porque a autonomia do indivíduo deve ser sempre protegida e tal proteção demanda, muitas vezes, a interferência na sua liberdade. Isso implica legitimar a interferência na escolha de alguém se sua opção for capaz de limitar ou eliminar sua autonomia no futuro. E, dentro dos limites do direito penal mínimo, nem sempre a preservação da autonomia deve ser efetivada por meio de incriminações, pois o Estado é dotado de outros meios para o resguardo da autonomia individual e para alcançar o bem estar social. É de se defender, portanto a existência de aspectos objetivos e subjetivos nos interesses que são levados à tutela pelo direito penal, já que o ser humano autônomo é a pessoa mais indicada para saber o que é bom para si mesmo, entretanto, o exercício desta autonomia necessita de proteção do Estado. E a tutela da autonomia se dá quando se consideram alguns bens jurídicos indisponíveis que, em determinadas situações, resguardam a autonomia do indivíduo. Isso significa que um bem pode ser disponível ou indisponível de acordo com a situação em que se encontra seu titular.

Com efeito, a norma jurídica possui caráter universal, é dirigida a todas as pessoas, assim como o bem estar social. Por conseguinte, não é possível legislar individualmente, ou seja, criar normas para proteger os interesses de cada indivíduo de acordo com suas preferências. Não é viável ao Estado elaborar normas individuais para resguardar interesses de cada 
pessoa. Essa é o maior entrave ao utilitarismo subjetivista. Por outro lado, ficar restrito às escolhas discricionárias do Estado, como se este determinasse aquilo que é melhor a cada um, seria permitir um paternalismo exacerbado para a imposição de valores estabelecidos independentemente da autonomia do sujeito. ${ }^{68} \mathrm{O}$ interesse maior que o direito deve garantir no estado liberal é o exercício da autonomia individual por meio da tutela dos bens jurídicos necessários, o que implica na admissão de que o Estado deve utilizar o direito penal para proteger somente aqueles bens jurídicos responsáveis pelo livre desempenho da autonomia quando não houver outros meios para garanti-lo. E tal remete ao princípio da lesão a terceiros (harm to others), segundo o qual é justificável a interferência na liberdade de uma pessoa quando houver lesão (ou perigo de lesão) a interesses alheios. Todavia, nas hipóteses em que não existir autonomia suficiente para decidir pela disponibilidade do bem jurídico, é legítimo invocar o princípio da autolesão (harm to self), pois o indivíduo não pode dispor de algo sem ter condições para tal. Enfim, tanto o princípio da lesão a terceiros quanto o princípio da autolesão podem sustentar a legitimidade de uma infração criminal. E, apesar de cada um saber o que é melhor para si mesmo, tal afirmativa só é completamente correta se existir autonomia para decidir e seguir adiante nas preferências individuais.

Por isso, do conflito aparente entre subjetivistas e objetivistas, é preciso confirmar a existência de um valor objetivo que deve coexistir com as preferências individuais de cada um: a autonomia. E, diante das dificuldades de se estabelecerem critérios objetivos de valores que devem ser assegurados pelo Estado, uma vez que cada pessoa tem o direito de decidir sobre sua própria vida, a autonomia surge como o mais importante interesse a ser preservado pelo direito penal, de modo que, na defesa da manutenção do princípio da subsidiariedade penal, a autonomia deve ser considerada o interesse mais importante, devido à sua função essencial ao desenvolvimento da vida de acordo com as preferências inerentes a si próprio. E, assim, os meios que o Estado deve proporcionar ao exercício da

68 VITA, Álvaro de. O que há de errado com o utilitarismo de preferências? In: CARVALHO, Maria Cecília Maringoni de (org.) O utilitarismo em foco. Florianópolis: Editora da UFSC. 2007. p. 207. 
autonomia são, em verdade, objetivos para que, subjetivamente, cada um desempenhe seu papel social de acordo com suas próprias preferências.

Há cerca de meia década, o Supremo Tribunal Federal enfrentou uma forte situação de ponderação de valores relacionados aos limites da intervenção penal, dessa vez para concluir pelo afastamento da proibição da conduta. Ocorreu no julgamento da Arguição de Descumprimento de Preceito Fundamental 54/DF, que considerou inconstitucional a interpretação de que a interrupção da gravidez de feto anencéfalo é uma conduta tipificada nos artigos 124, 126 e 128, incisos I e II, do Código Penal. ${ }^{69} \mathrm{Na}$ ocasião, o relator do caso, o Ministro MARCO AURÉLIO, considerou que o fato atípico sob o argumento de que o feto anencéfalo é um natimorto cerebral, o que impede considerar a existência de vida no sentido biológico, por falta de viabilidade, ou jurídica, por ausência de atividade cerebral, bem como que, diante de uma ponderação entre seu suposto direito à vida e os direitos da mulher à dignidade humana, liberdade, autonomia de escolha, privacidade, bem como de seus direitos sexuais e reprodutivos, estes últimos justificam a atipicidade do fato. ${ }^{70} \mathrm{O}$ Ministro CEZAR PELUSO afirmou que o aborto de feto anencéfalo é crime, pois, além de existir vida humana, algo que independe da especulação sobre sua viabilidade futura, nem o sofrimento psíquico, nem os direitos à autonomia da vontade e liberdade de escolha da mulher, não degradam, em si, a dignidade humana a ponto de permitir a prática de tal crime. ${ }^{71} \mathrm{O}$ Ministro JOAQUIM BARBOSA entendeu que o fato é atípico também devido à ausência de vida humana viável no feto anencéfalo e que seria uma contradição resguardar a liberdade e a autonomia privada da mulher no caso de aborto sentimental e proibir o exercício dessa liberdade nos casos em que há má-formação fetal grave, como a anencefalia e, portanto, não existe

69 STF, ADPF 54/DF, Tribunal Pleno, relator Ministro Marco Aurélio, julgado em 12 de abril de 2012.

${ }^{70}$ STF, ADPF 54/DF, Voto do Ministro Relator Marco Aurélio, p. 32 e ss. do Inteiro Teor do Acórdão.

${ }^{71}$ STF, ADPF 54/DF, Voto do Ministro Cezar Peluso, p. 88; 375-376 e ss. do Inteiro Teor do Acórdão. 
um conflito real de bens merecedores de proteção jurídica. ${ }^{72} \mathrm{O}$ Ministro LUIZ FUX considerou que, se o legislador admite a supressão da vida de um feto sadio para proteger a saúde psíquica da mulher, é possível reconhecer um estado de necessidade supralegal nas hipóteses de aborto de feto anencéfalos, já que, do contrário, seria uma grave desproporcionalidade. $^{73} \mathrm{O}$ Ministro RICARDO LEWANDOWSKI, por sua vez, afirmou que, diante da univocidade das palavras do texto legal que trata do aborto, não caberia ao Supremo Tribunal Federal reinterpretá-lo, mas legar ao Congresso a tarefa de afastar ou não a incriminação do aborto de feto anencéfalo. ${ }^{74} \mathrm{O}$ Ministro AYRES BRITTO julgou que o fato é atípico, por faltar vida em potencial no feto anencéfalo. ${ }^{75} \mathrm{O}$ Ministro GILMAR MENDES argumentou que, diante os valores e bens jurídicos protegidos, saúde física e psíquica da mãe, o aborto de anencéfalo seria um fato típico, mas de antijuricidade excluída. ${ }^{76}$ O Ministro CELSO DE MELLO também considerou o fato atípico devido à ausência de vida humana pela falta de atividade cerebral no feto anencéfalo, de modo que sua proteção não justifica a restrição nos direitos fundamentais da mulher grávida, bem como que, mesmo que o comportamento fosse considerado típico, seria o caso de inexigibilidade de conduta diversa, causa supralegal excludente de culpabilidade, em razão do sofrimento físico e/ou psíquico, com dano à saúde e inclusive risco de morte à gestante. ${ }^{77}$ Por fim, a Ministra ROSA WEBER entendeu que o fato é atípico devido à ausência de vida humana diante da inexistência de atividade cerebral e capacidade para o

\footnotetext{
${ }^{72}$ STF, ADPF 54/DF, Voto do Ministro Joaquim Barbosa, p. 145 e ss. do Inteiro Teor do Acórdão

73 STF, ADPF 54/DF, Voto do Ministro Luiz Fux, p. 154 e ss. do Inteiro Teor do Acórdão. ${ }^{74}$ STF, ADPF 54/DF, Voto do Ministro Ricardo Lewandowski, p. 237 - 238 e ss. do Inteiro Teor do Acórdão.

75 STF, ADPF 54/DF, Voto do Ministro Ayres Britto, p. 254 e ss. do Inteiro Teor do Acórdão.

${ }^{76}$ STF, ADPF 54/DF, Voto do Ministro Gilmar Mendes, p. 267 - 271 e ss.; p. 310 e ss.; p. 312 e ss. do Inteiro Teor do Acórdão.

77 STF, ADPF 54/DF, Voto do Ministro Celso de Mello, p. 313 e ss. do Inteiro Teor do Acórdão.
} 
convívio social, bem como que o direito penal estabelece uma gradação em importância da proteção da vida de acordo com o seu desenvolvimento. ${ }^{78}$

Como é de se observar, embora a discussão da ADPF 54/DF tenha se limitado aos casos de interrupção da gravidez de feto anencéfalo, os votos que levaram ao reconhecimento da atipicidade de tal comportamento ponderaram diversos valores gerais, como direitos da mulher, dignidade humana, liberdade, autonomia, privacidade, direitos sexuais e reprodutivos, direito à integridade física e psíquica, que podem ser levantados em outras hipóteses de interrupção da gravidez. E mesmo o argumento que parece mais restrito, da inviabilidade da vida humana, também pode, eventualmente, ser utilizado frente a outras espécies de enfermidade graves. Assim, mesmo que já tenha cumprido o seu papel de estabelecer o limite da intervenção penal nas hipóteses de aborto de feto anéncefalo, a ponderação realizada por esse julgamento do Supremo Tribunal Federal tem potencial para suscitar novas discussões e esclarecer os limites da punição estatal em relação a outros casos de interrupção de gravidez.

\section{CONCLUSÃO}

Portanto, é possível observar que o Supremo Tribunal Federal em diversas ocasiões enfrentou hipóteses, seja no julgamento de casos concretos, seja no controle de constitucionalidade em abstrato de leis, semelhantes àquelas tratadas pela teoria do paternalismo jurídico-penal e utilizou, ainda que intuitivamente, ferramentas de interpretação semelhantes às desenvolvidas em suas estruturas. Por isso, uma aproximação de sua jurisprudência aos argumentos que giram em torno do paternalismo penal, com o fim de esclarecer os limites da intervenção penal do Estado no âmbito de liberdade individual do cidadão, poderia tanto reforçar o caminho da construção de um direito penal liberal na Corte Suprema quanto evitar legitimar a normas paternalistas que firam a autonomia do indivíduo e/ou proíbam comportamentos que não ocasionem nenhum dano às outras pessoas ou à coletividade em sentido amplo.

${ }^{78}$ STF, ADPF 54/DF, Voto da Ministra Rosa Weber, p. 420 e ss. do Inteiro Teor do Acórdão. 
No entanto, qualquer reconhecimento da existência de normas penais paternalistas pela jurisprudência de nossa mais alta corte precisa partir da premissa de que a construção de uma teoria paternalista legítima do direito penal exige, necessariamente, atenção aos conceitos de autonomia e responsabilidade. Isso porque o sujeito autônomo é aquele que sabe discernir as coisas e pode agir conforme sua vontade consciente. Tal autonomia a ser preservada, contudo, não é irrestrita, pois se esgota quando interferir na autonomia de terceiros. E, na ausência da capacidade de discernimento ou da livre manifestação da vontade, por qualquer tipo de vulnerabilidade, não se reconhece um comportamento como autônomo, o que pode levar à legitimidade de uma intervenção paternalista. $\mathrm{O}$ direito penal, assim, pode agir paternalisticamente na proteção de bens jurídicos, mas desde que se tratem de bens jurídicos fundamentais à preservação da autonomia individual, que o indivíduo que sofre a restrição em sua liberdade não seja uma pessoa autônoma, e que o respectivo bem jurídico seja capaz de garantir sua autonomia presente e futura. Ao se adotar tais premissas, o debate sobre a legitimidade e o alcance de normas penais de conteúdo paternalista pode se tornar mais esclarecido.

\section{REFERÊNCIAS}

ALEMANY, Macario. Elpaternalismo juridico. Madri: Iustel. 2006

ANJOS, Marcio Fabri dos. A vulnerabilidade como parceira da autonomia. Revista da Sociedade Brasileira de Bioética, Brasília, DF, vol. 02, n. ${ }^{\circ}$ 02, 2006.

BRINK, David O. Mill's Deliberative Utilitarianism. Philosophy and Public Affairs, vol. 21, n. ${ }^{\circ}$ 01, pp. 67-103, 1992.

CARTER, Ian. Positive and Negative Liberty. Stanford Encyclopedia of Philosophy. Disponível em <http://plato.stanford.edu/entries/libertypositive-negative/>. Acesso em: 11/06/2014. 
CASTRO, Mary Garcia; ABRAMOVAY, Miriam. Jovens em situação de pobreza, vulnerabilidades sociais e violências. Cadernos de Pesquisa da Fundação Carlos Chagas, São Paulo, n. 116, jul. 2002.

CHRISTMAN, John. Autonomy in Moral and Political Philosophy. Stanford Encyclopedia of Philosophy. Disponível em: $<$ http://plato.stanford.edu/entries/autonomy-moral/>. Acesso em: 10/06/2014.

DUFF, R. A. Towards a Modest Legal Moralism. Legal Studies Research Paper Series - Research Paper n. 12-28, University of Minnesota Law School.

DWORKIN, Gerald. Paternalism. In: FEINBERG, J.; GROSS, H. (orgs.). Philosopby of Law. Encino (EUA): Dickenson Publisling. 1975.

DWORKIN, Gerald. The Theory and Practice of Autonomy. Nova Iorque: Cambridge University Press. 1988.

FEINBERG, Joel. Harm to others. Nova Iorque: Oxford. 1984.

GRECO, Luís. Casa de prostituição (art. 229 do CP) e direito penal liberal: reflexões por ocasião do recente julgado do STF (HC 104.467). In; Revista Brasileira de Ciências Criminais 92. São Paulo: Editora Revista dos Tribunais, 2011.

GUIMARÃES, Maria Carolina S.; NOVAES, Sylvia Caiuby. Autonomia reduzida e vulnerabilidade: liberdade de decisão, diferença e desiguldade. Revista Bioética, Brasília, DF, vol. 07, n. ${ }^{\circ}$ 01, 1999.

GUIMARÃES, Maria Carolina S., NOVAES, Sylvia Caiuby. Vulneráveis. Portal da Bioética da Universidade Federal do Rio Grande do Sul.

HUNGRIA, Nelson. Comentários ao Código Penal, vol. VII. Rio de Janeiro: Forense. 1955. p. 164. 
HUTZ, Claudio S., KOLLER, Silvia H., BANDEIRA, Denise R. Resiliência e vulnerabilidade em crianças em situação de risco. In: KOLLER, Silvia Helena. Coletâneas da Associação Nacional de Pesquisa e Pós-graduação em Psicologia, Rio de Janeiro, n. ${ }^{\circ}$ 12, 1996.

FERRARA, Alessandro. Two Notions of Humanity and the Judgment Argument for Human Rights. Political Theory, Thousand Oaks, vol. 31, n. ${ }^{\circ}$, jun. 2003.

FEINBERG, Joel. Harm to self. Nova Iorque: Oxford. 1986.

JAREBORG, Nils. Criminalization as Last Resort (Ultima Ratio). Obio State Journal Of Criminal Law, Columbus, vol. 02, 2004.

MINAHIM, Maria Auxiliadora. O consentimento do ofendido em face dos bens jurídicos indisponíveis. Revista de Ciências Jurídicas, Belo Horizonte, vol. 06, n. ${ }^{\circ}$ 01, jan./jun. 2008.

MURPHY, Jeffrie G. Legal Moralism and Liberalism. Arizona Law Review, vol. 37, 1995.

O’MANIQUE, John. Universal and inalienable rights: a search for foundations. Human Rights Quarterly, Baltimore, vol. 12, n. ${ }^{\circ} 4$, pp. 465485, nov. 1990.

PERRY, Thomas D. Moral Autonomy and Reasonableness. The Journal of Philosophy, Oxford, vol. 65, jun. 1968.

READER, Soran. New Directions in Ethics: Naturalisms, Reasons and Virtue. Ethical Theory and Moral Practice, Amsterdan (Holanda), vol. 3, n. ${ }^{\circ}$ 04, dez. 2000.

SANTIAGO NINO, Carlos. Ética e derechos humanos. Buenos Aires: Astrea. 2007. 
SCANLON, T. M. Preference and urgency. The Journal of Philosophy, Oxford, vol. 72, n. $^{\circ} 19,1975$.

SCANLON, T. M., DANCY, Jonathan. Proceedings of the Aristotelian Society, Londres, Vol. 74, 2000.

SEGRE, Marco, LEOPOLDO E SILVA, Franklin, SCHRAMM, Fermin R. O contexto histórico, semântico e filosófico do princípio de autonomia. Bioética, Brasília, DF, vol. 06, 1998.

SILVA, Algéria Valéria da. Vulnerabilidade social e suas consequências: o contexto educacional da juventude na região metropolitana de Natal. In: 13. ${ }^{\circ}$ ENCONTRO DE CIÊNCIAS SOCIAIS DO NORTE NORDESTE, Maceió, 2007.

SZERLETICS, Antal. Paternalism. Essex Autonomy Project Green Paper Report. Londres: University of Essex. 2011.

VITA, Álvaro de. O que há de errado com o utilitarismo de preferências? In: CARVALHO, Maria Cecília Maringoni de (org.) O utilitarismo em foco. Florianópolis: Editora da UFSC. 2007.

WERTHEIMER, Alan. Exploitation. In: Stanford Encyclopedia of Philosophy. Disponível em: $<$ http://plato.stanford.edu/entries/exploitation/>. Acesso em: 17 jun. 2010.

ZANER, Richard M. The Phenomenon of Vulnerability in Clinical Encounters. Human Studies, Holanda, vol. 29, n. ${ }^{\circ}$ 3, set. 2006. 